\author{
Katarzyna Kaczor \\ Uniwersyłet Gdański \\ ORCID: 0000-0003-2897-2904
}

\title{
Nazywam się Mróz. Remigiusz Mróz. O kreacji marki autorskiej/literackiej w polskim polu literackim/kultury
}

\begin{abstract}
Streszczenie
Przedmiotem artykułu jest analiza funkcjonowania w polskim polu kultury Remigiusza Mroza jako autora mającego na celu uykreowanie identyfikowanej z nim własnej marki literackiej. Celem przeprowadzonych badań było prześledzenie mechanizmów służących autokreacji marki literackiej w przestrzeni kultury mainstreamu z uwzględnieniem: uwarunkowań funkcjonowania polskiego rynku wydawniczego, sposobów wykorzystania mediów społecznościouych i opiniotwórczych w celach autoprezentacji oraz dyskursu krytycznego jego twórczości. Wnioski sformułowano u kontekście uyników badań uspółczesnego polskiego pola literackiego prowadzonych z perspektywy badań kulturowych.
\end{abstract}

Słowa kluczowe: Remigiusz Mróz, marka literacka, polskie pole literackie u XXI wieku, polska literatura popularna XXI wieku, rynek wydawniczy, marketing w polu kultury.

\section{My name is Mróz. Remigiusz Mróz.}

On the creation of an author / literary brand in the Polish literary / cultural field

\section{Abstract}

The subject of the article is the analysis of the functioning in the Polish cultural field of Remigiusz Mroz as an author aiming to create his own literary brand identified with it. The aim of the conducted research was to follow the mechanisms for self-creation of the literary brand in the mainstream culture, including: conditions of the Polish publishing market, ways of using social media and opinion-making media for self-presentation and critical discourse of his work. The conclusions were formulated in the context of the results of the research of the contemporary Polish literary field conducted from the perspective of cultural research.

Keywords: Remigiusz Mróz, literary brand, Polish literary field in the 21st century, Polish popular literature of the 21st century, publishing market, marketing in the field of culture.

\section{Wprowadzenie}

Trzydzieści dwie opublikowane książki i ponad dwa miliony sprzedanych egzemplarzy w ciągu pięciu lat od debiutu. Nagroda Czytelników Wielkiego Kalibru dla najlepszej polskiej powieści kryminalnej roku. Pięć, ukazujących się równolegle, powieściouych 
cykli, z których pieruszy, najbardziej popularny, zaadaptowany na serial miał suoją premierę zimą 2018 roku, a prawa do adaptacji dwóch następnych zostały już sprzedane ${ }^{1}$. Trzydziestoduulatek, który zrezygnował z kariery prawnika na rzecz realizacji swojego marzenia i został poczytnym pisarzem. Nieustannie, od 2013 roku publikujący, obecny i komunikujący się ze swoimi czytelnikami przez media społecznościowe, i promujący swoją twórczość u kontekście spełnionego marzenia, kolejnych realizowanych celów i komercyjnego sukcesu. Z wszystkich wymienionych powodów, swoją aktywność i rozpoznawalność Remigiusz Mróz, a właściwie identyfikowana z nim marka autorska, jest fenomenem w polskim polu literackim drugiej dekady XXI wieku. Przy czym marka na potrzeby tego artykułu będzie definiowana jako nazwa, którą jest nazwisko autora, identyfikujące i odróżniające jego twórczość od wydawnictw innych autorów.

Prześledzenie funkcjonowania Remigiusza Mroza w polu kultury, oparte na analizie polityki wydawniczej dotyczącej publikacji jego twórczości, jego aktywności i treści udostępnianych za pośrednictuem mediów społecznościouych oraz wypowiedzi udzielanych w mediach tradycyjnych, a także jego konsekwentnej wizualnej autoprezentacji, umożliwia sformułowanie tezy, że jego działania mają charakter właściuy dla:

a) kształtowania marki w zakresie jej wizerunku i świadomości w polskim polu kultury, definiouanym za Pierrem Bourdieu jako „społeczny mikrokosmos, w którym produkowane są obiekty kulturowe"2;

b) tworzenia kolejnych książek na podstawie zbioru atrybutów nadających im niepoutarzalną (w kontekście twórczości konkurentów, czyli polskich autorów literatury sensacyjnej, obejmującej swoim zakresem powieści kryminalne, thrillery i horrory) jakość, co ułatwia ich odróżnianie, ułatwia dokonywanie uyboru i skutkuje jego poutarzalnością ze strony konsumentów, będących lojalnymi czytelnikami „Mroza”, na co wskazują posty zamieszczone w portalu Lubimyczytać.pl ${ }^{3}$ i na profilach Remigiusza Mroza u portalach Facebook ${ }^{4}$ Instagram $^{5}$ i Twitter 6 .

Przeprowadzona analiza ze względu na przedmiot, jakim jest kształtowanie i funkcjonowanie marki autorskiej Remigiusz Mróz, mieści się w zakresie badań kulturouych, przedmiotem których jest badanie polskiego pola literackiego? Ze względu na swojego bohatera, jakim jest autor literatury gatunkowej, poszerza pole refleksji wyznaczone przez prace poświęcone kreacji marek i wizerunków: Michała Witkouskiego i Jacka

\footnotetext{
${ }^{1}$ Mojebestsellery, Nowa część Chytki już w marcu!, granice.pl Wszystko o literaturze, https:// wuw.granice.pl/news/nowa-czesc-chylki-juz-w-marcu/8007 (dostęp: 06.03.2019).

2 W tekście będę posługiwała się koncepcją pola sformułowaną przez Pierre'a Bourdieu, Teoria obiektów kulturowych, przeł. A. Zawadzki [w:] Odkrywanie modernizmu. Przekłady $i$ komentarze, red. R. Nycz, TAiWPN Universitas, Kraków 1998, s. 266.

${ }^{3}$ http://lubimyczytac.pl/autor/82094/remigiusz-mroz (dostęp: 06.03.2019).

${ }^{4}$ https://wuw.facebook.com/remigiusz.mroz/ (dostęp: 06.03.2019).

${ }^{5}$ https://www.instagram.com/remigiuszmroz/?fbclid=IwAR2jNqRukvT9dozKz65PAh-fGDL1xev-7uifUFzMXAoUJWxQbl1MBn7JCWM (dostęp: 06.03.2019).

${ }^{6}$ https://twitter.com/remigiuszmroz (dostęp: 06.03.2019).

${ }^{7}$ Literatura polska po 1989 roku w świetle teorii Pierre'a Bourdieu. Podręcznik, red. G. Jankowicz, P. Marecki, M. Sowiński, Korporacja Ha!art, Kraków 2015.
} 
Dehnela oraz Andrzeja Sapkouskiego i Wita Szostakå․ Jednocześnie uskazując na wzrastającą rolę mediów społecznościouych i tradycyjnych w komunikacji autora, dysponenta marki, a otoczeniem.

\section{I pojawił się Mróz. Remigiusz Mróz}

Kiedy trzy lata po suoim debiucie, u 2016 roku Remigiusz Mróz został laureatem Nagrody Czytelników Wielkiego Kalibru za otwierającą cykl JoAnna CHYŁKa Kasację $(2015)^{9}$, na antenie TVP2 w poprzedzającej rozmowę z nim zapowiedzi został przedstawiony jako:

\section{REMIGIUSZ MRÓZ - NOWA TWARZ POLSKIEGO KRYMINAŁU}

Ma zaleduie 29 lat, a na suoim koncie już kilka bestsellerów - na naszych kanapach Remigiusz Mróz - mistrz kryminału i doktor prawa. Remigiusz Mróz - zdobył w tym roku najbardziej prestiżową polską nagrodę dla pisarza kryminałów: Nagrodę Wielkiego Kalibru, na liście bestsellerów Empiku przegonił Bondę i Miłoszeuskiego, mieszka pod Opolem, zrobił doktorat z prawa na Akademii Leona Koźmińskiego (ukończył studia z uyróżnieniem), studiował w Warszawie, po czym wrócił w rodzinne strony, napisał ponad 30 książek i teraz je po kolei wydaje (w tym roku wyda łącznie aż 8!), sprzedał prawa do ekranizacji swojej trylogii kryminalnej z komisarzem Forstem. Ciekawostki na temat autora: niesamowicie zdyscyplinowany, tygodniowo przebiega średnio 100 kilometrów, kocha góry; prowadził Kurs Pisania na portalu Lubimy Czytać. Jego słynna trylogia z komisarzem Forstem to: Ekspozycja (Nieuchwytny zabójca, mroczna tajemnica z przeszłości) ; Przewieszenie (góry jeszcze nigdy nie były tak niebezpieczne); Trawers (Wszystkie pożary zgasły. Zostały tylko zgliszcza) ${ }^{10}$.

A bohaterem, którego przytoczona wypowiedź telewizyjnego spikera poprzedzała, okazał się młody, starannie ostrzyżony, ubrany w garnitur, białą koszulę i krawat młody mężczyzna, dla którego pisanie jest pasją, a bycie pisarzem taką samą profesją jak każda inna, wymagająca warsztatu, samodyscypliny i determinacji w osiąganiu wyznaczonych celów. Wymykający się stereotypowi literata-wieszcza i artysty, wpisujący się w paradygmat dobrze ubranego, osiągającego sukces finansouy profesjonalisty, który w polskim polu literackim zaistniał za sprawą Szczepana Twardocha.

\footnotetext{
${ }^{8}$ Analizę przypadków Michała Witkouskiego i Jacka Dehnela przeprowadził Dominik Antonik u idem, Autor jako marka, TAiWPN Universitas, Kraków 2014; o kreowaniu marki przez Andrzeja Sapkouskiego pisałam w: K. Kaczor, $Z$, getta” do mainstreamu. Polskie pole literackie fantasy (1982-2012), TAiWPN Universitas, Kraków 2017; strategii kreowania wizerunku przez Wita Szostaka szerzej: K. Kaczor, Wit Szostak - wizerunek akademika przeistaczajacego się w literata, „Horyzonty Wychowania” 2017, vol. 16, no. 39, s. 59-74.

${ }_{9}$ Dla czytelności tekstu tytuły cykli powieściouych będą podawane kapitalikami, ponadto przy pieruszym przywołaniu tytułów książek autorstwa Remigiusza Mroza będą podawane u nawiasach daty ich pierwodruków, natomiast ich pełne dane bibliograficzne zostały zamieszczone w Bibliografii artykułu.

${ }^{10}$ Pytanie na śniadanie, wydanie z dnia 22.07.2016, http://pytanienasniadanie.tvp.pl/26250763/ remigiusz-mroz-nowa-twarz-polskiego-kryminalu (dostęp: 06.03.2019).
} 
Sposób, w jaki Remigiusz Mróz pojawił się w polskim polu literackim, okazał się zgoła odmienny od tego, w jakim zazuyczaj pojawiają się debiutanci. Po pierwsze, nie został przez nikogo „odkryty”, jak na przykład Dorota Masłouska przez uznanego wydawcę czy krytyka, jakim był Paweł Dunin-Wąsowicz, lecz sięgnął po swój sukces sam, rozsyłając suoje rękopisy do różnych uydawców ${ }^{11}$, co zaowocowało publikacjami w tym samym czasie wielu tekstów w różnych oficynach. I tak zadebiutował w 2013 roku powieściami Wieża milczenia i Prędkość ucieczki, która zainicjowała pieruszy z jego cykli Parabellum (Horyzont zdarzeń, 2014; Gtębia osobliwości, 2016), ale przełomem w jego karierze okazało się opublikowanie w 2015 roku pierwszych tomów duóch nourch cykli spod znaku powieści kryminalnej i jej uspółczesnych interpretacji. Pierwszego, zatytułowanego Komisarz Fonst (Ekspozycja, 2015; Przewieszenie, 2016; Trawers, 2016; Deniwelacja, 2017; Zerwa, 2018), którego poetyka inspirowana jest kryminałem skandynauskim, ale akcja jest osadzona w realiach polskiego Podhala; i drugiego JoAnna ChYєKa (Kasacja i Zaginięcie, 2015; Rewizja i Immunitet, 2016; Inwigilacja i Oskarżenie, 2017; Testament i Kontratyp, 2018; Umorzenie, 2019), inspirowanego thrillerami prawniczymi Johna Grishama, ale którego bohaterami są pracounicy firmy prawniczej mającej siedzibę $\mathrm{w}$ przylegającym do warszauskich Złotych Tarasów wieżowcu Sky Light, co symbolicznie sytuuje akcję w samym centrum polskiej rzeczywistości anno domini 2015. Obu konsekwentnie publikowanych w poznańskich wydawnictuach: Fili (KomisArz Forst) i Czwarta Strona (JoAnNA CнYєKA), nakładem których do marca 2019 roku ukazało się 25 powieści, spośród których 20 było przypisanych do pięciu odrębnych cykli: ParabelLum (2013-2015), Komisarz Forst (2015-2018), Joanna ChYŁKa (2015-), W KręGaCh WŁadZy (Wotum nieufności i Większość bezwzględna, 2017; Wtadza absolutna, 2018), Nieodnaleziona (2018) i będąca jej kontynuacją Nieodgadniona (2019); oraz poradnik dla początkujących autorów O pisaniu na chłodno (2018).

Przy czym należy zauważyć, że równolegle, w latach 2018-2019 nakładem Wydaunictua Dolnośląskiego pod pseudonimem Ove Løgmansbø ukazała się ,jaunie” skandynawska Trylogia z Wysp Owczych (Enklawa i Połów, 2016; Prom, 2017). Tym samym na przestrzeni lat 2013 - marzec 2019 Remigiusz Mróz opublikował nakładem siedmiu wydawnictu trzydzieści trzy powieści, co daje oszałamiający wynik blisko pięciu woluminów rocznie, przy nadal wielu zaplanowanych i czekających na publikację. A krzywą progresu sumy opublikowanych książek Remigiusz Mroza przedstawiono na rycinie 1 . ${ }^{11}$ R. Mróz, Jak wydać ksiażkę, Remigiusz Mróz blog, http://blog.remigiuszmroz.pl/jak-uydac-
-ksiazke/ (dostęp: 06.03.2019). 
Nazywam się Mróz. Remigiusz Mróz...

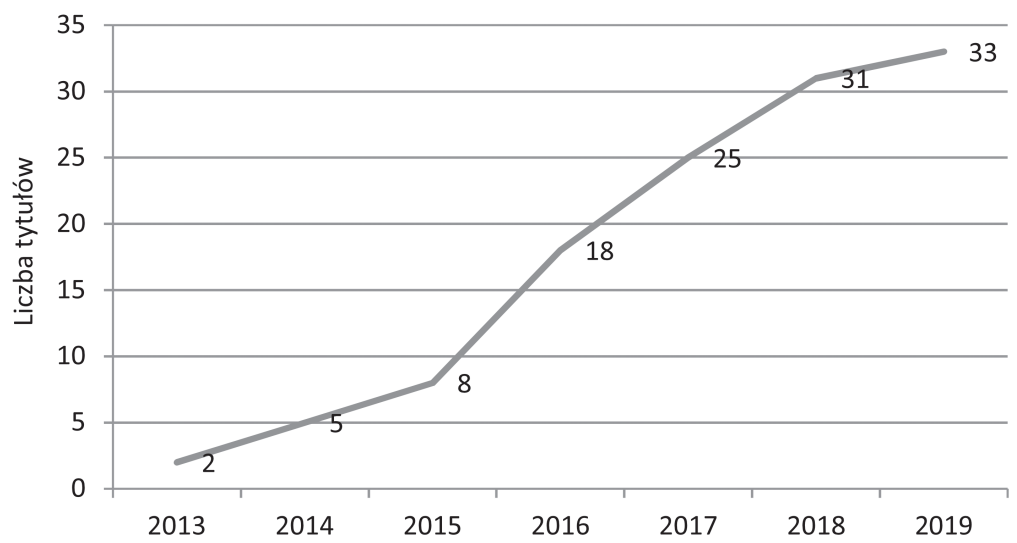

Rycina 1. Liczba opublikowanych książek Remigiusza Mroza Żródło: wyniki badań własnych.

Uwzględniając swoistą płytkość polskiego rynku wydawniczego i poziom czytelnictua, to podkreślane przez samego Remigiusza Mroza sprzedanie ponad dwóch milionów egzemplarzy książek w pieruszych pięciu lat od debiutu, czyli do końca 2017 roku $^{12}$ - jest sukcesem komercyjnym.

Remigiusz Mróz od początku przedstawiał siebie jako twórcę literatury gatunkowej, autor: powieści wojennej (Parabellum, Turkusowe szale, 2014), powieści science fiction (Chór zapomnianych głosów, 2014), kryminału (KomISARz Fonst, Behawiorysta, Trylogia Wysp OwCZYCh), thrillera prauniczego (JoAnna CHYŁKA), horroru religijnego (Czarna Madonna, 2017), wywiedzionego z political fiction thrillera politycznego (W KręGACH WŁADZY), thrillera psychologicznego (Nieodnaleziona i Nieodgadniona), wskazując na swoje wzorce i poziom aspiracji, jakim jest sukces komercyjny swojej twórczości. Przywołując $w$ swoich wypowiedziach publikowanych $w$ mediach społecznościouych w latach 2014-2016, a od 2016 roku w wywiadach źródła swoich inspiracji: Stiega Larssona, Jane K. Rowling, Stephena Kinga, Johna Grishama i innych autorów sprzedawanych w milionowych nakładach bestsellerów ${ }^{13}$. Jednoznacznie sytuując swój sukces w kontekście amerykańskiego mitu self-made mana, czyli człowieka uszystko zaudzięczającego sobie, i jak sam uskazuje american dream, dla realizacji którego nie ma granic. Co poskutkowało samodzielnym zdobyciem wydawcy polskiego (Wieża milczenia; PARABELLum); podjęciem próby publikacji na rynku angloamerykańskim powieści Nieodnaleziona (2018) i sprzedażą praw do adaptacji na serial telewizyjny cykli: JoAnNa ChYŁKA (pierwszy sezon zrealizowany na podstawie Zaginięcia miał

${ }_{12}$ Wypowiedź R. Mroza podczas uywiadu udzielonego Wojciechowi Jagielskiemu w Superstacji; Wojtek Jagielski na żywo - Remigiusz Mróz, 6.11.2017, wwu.superstacja.tv, http://www. superstacja.tv/program/wojtek-jagielski-na-zywo-remigiusz-mroz,6555416/ (dostęp: 06.03.2019).

13 R. Mróz, Jak wydać książkę..., op. cit. 
premierę 26.12.2018 na platformie Player ${ }^{14}$ ), Komisarz Frost i W KręGaCh WŁadzY zaplanowane do realizacji przez TVN po sukcesie pierwszego sezonu serialu Chytka.

Od momentu debiutu Remigiusza Mroza publikacji jego tekstów literackich towarzyszyła autokreacja wizerunku i komunikacja z czytelnikami za pośrednictwem profili w mediach społecznościouych, które stały się źródłem informacji redystrybuowanych następnie przez media opiniotwórcze. Pierwotnie był nim autorski blog Remigiusz Mróz i mający taką samą nazwę profil w portalu Lubimyczytać.pl, gdzie również publikował latach 2014-2015 cykl artykułów Kurs pisania ${ }^{15}$, które znalazły się również w opublikowanej w 2018 roku książce Kurs pisania na chłodno (2018). Następnie pojawiły się jego oficjalne profile na FB, Instagramie i Tuitterze, które umożliwiają mu informowanie na bieżąco o: nowych książkach, spotkaniach z czytelnikami, uczestnictwie w targach książki, odbytych podróżach i wakacjach, udzielonych wywiadach, przebiegu prac i promocji serialu, sesji fotograficznej do magazynu lifestylowego „Viva”.

Mimo że pieruszy wywiad z Remigiuszem Mrozem ukazał się na łamach Gazety Opole z okazji premiery Kasacji (Jest prawnikiem, ma 28 lat i napisał już... 30 książek. Nałóg? ${ }^{16}$, komunikacja za pośrednictuem mediów tradycyjnych: prasy, telewizji i radia nastąpiła dopiero po otrzymaniu przez Remigiusza Mroza Nagrody Czytelników Wielkiego Kalibru. Pierwotnie występował w roli „ciekawostki” ze świata polskiej literatury w telewizji śniadaniowej, następnie autora bestellerów i niezrozumiałego z perspektywy mediów opiniotwórczych fenomenu, jakim jawił się w artykułach: Justyny Sobolewskiej w „Polityce” (Polski horror religijny ${ }^{17}$ ) i Krzysztofa Vargi w „Dużym Formacie” „Gazety Wyborczej” (Remigiusz Mróz: żadnych ciuchów, samochodów, podróży! i Varga uczy się od Remigiusza Mroza, jak pisać i jak zarobić duże pieniądze $)^{18}$, czy wręcz grafomana o wizerunku „pracowitego dorosłego chłopczyka. Czytelnicy dostają razem z nim guarancję: «Nigdy was nie zawiodę, moje książki będziecie mogli czytać do końca życia»” w „Gazecie Książkach”'. Aż po autora wiarygodnego portretu

14 https://promocja.player.pl/playerplus-chylka-zaginiecie?ap=1t1\&gclid=CjwKCAiA_ P3jBRAqEiwAZyWWaL6KYG7fMUx-fNfvI8kemmep5Go-gxcA0sE9hJc9hCG_Zi8YQol2pRoCyukQAvD_BuE\&gclsrc=aw.ds (dostęp: 06.03.2019).

${ }^{15}$ http://lubimyczytac.pl/profil/326641/remigiusz-mroz (dostęp: 06.03.2019).

16 P. Guzik, Jest prawnikiem, ma 28 lat i napisał już... 30 ksiażek. Nałóg?, Wyborcza.pl Opole, 3.05.2015, http://opole.wyborcza.pl/opole/1,35086,17852250,Jest_prawnikiem_ma_28_lat_i_ napisal_juz__30_ksiazek_.html (dostęp: 06.03.2019).

17 J. Sobolewska, Polski horror religijny, „Polityka” 18 lipca 2017, https://wwu.polityka.pl/ tygodnikpolityka/kultura/1712456,1,remigiusz-mroz-o-swojej-literackiej-drodze.read?print=true (dostęp: 06.03.2019).

${ }^{18}$ K. Varga, Remigiusz Mróz: żadnych ciuchów, samochodów, podróży!, Wyborcza.pl Duży Format, 19.02.2018, http://uyborcza.pl/duzyformat/7,127290,23028230,remigiusz-mroz-zadnych-ciuchou-samochodou-podrozy.html (dostęp: 06.03.2019); idem, Varga uczy się od Remigiusza Mroza, jak pisać i jak zarobić duże pieniądze, Wyborcza.pl Duży Format, 3.12.2018, http:// uyborcza.pl/duzyformat/7,127290,24224764,varga-uczy-sie-od-remigiusza-mroza-jak-pisac-i-jak-zarobic.html (dostęp: 06.03.2019).

${ }^{19}$ E. Wołkanouska-Kołodziej, Remigiusz Mróz: autor, który rozbił bank, Wyborcza. pl Książki. Magazyn do czytania, 16 maja 2017, Wyborcza.pl, http://uyborcza.pl/ksiazki/7,154165,21786469,remigiusz-mroz-autor-ktory-rozbil-bank.html (dostęp: 06.03.2019). 
polskiej rzeczywistości, jakim jest według Filipa Łobodzińskiego współprowadzącego emitowaną na antenie TVN24 Xięgarnię ${ }^{20}$, kreującego nieobecne w polskiej literaturze współczesnej silne bohaterki kobiece według Michała Nogasia z „Gazety Wyborczej ${ }^{21}$ czy podejmującego według Anity Karwouskiej trudne tematy społeczne ${ }^{22}$. Przy czym nieustannie pouracającymi informacjami w niemal wszystkich publikacjach, których bohaterem jest Remigiusz Mróz: są jego młody wiek, zwiększająca się liczba wydanych tytułów i obecny stan sprzedanych nakładów, co nieustannie kreuje go na człowieka komercyjnego sukcesu.

Kreator prawniczo-korporacyjnej love story Joanny Chyłki i Kordiana Ordona, zwanego przez swoją patronkę i ukochaną Zordonem, suoją wiarygodność budował na podstawie prestiżu zdobytego wykształcenia, co zostało również uykorzystane przez niego w celu wykreowania znanego z kulturowych reprezentacji korporacji wizerunku profesjonalisty skoncentrowanego na swojej pracy i osiąganiu kolejnych celów, co podkreśla jego zuniformizowany ubiór: klasyczna w kroju ciemna marynarka lub garnitur, jasna koszula i jednolity stonowany krawat. Swoistym kontrapunktem do tego wizerunku są nieliczne zdjęcia Remigiusza Mroza przedstawiające go podczas wędrówek górskich w odzieży sportowej marki własnej popularnego sklepu sportowego ${ }^{23}$, co niweluje dystans kreowany przez jego wizerunek profesjonalisty i przez jej egalitarność podkreśla identyfikację z czytelnikami własnych powieści.

Komunikacja dotycząca twórczości i osoby autora W KręGACH WŁadzY od samego początku miała charakter demitologizujący i została oparta na podkreślaniu swoistej niezuykłości i antynomii: uybór tworzenia literatury zamiast praktykowania prawa; opuszczenie centrum reprezentowanego przez Warszawę na rzecz powrotu na peryferia reprezentowane przez Opolszczyznę; odnoszenie spektakularnego sukcesu i niewypowiadanie się na tematy niezwiązane z własną twórczością; dysproporcja młodego wieku i liczby publikowanych tytułów; kult rzemiosła i samodyscypliny w miejscu natchnienia i tworzenia jako czynności kompulsywnej, a przez to mającej aspekt destrukcyjny. Te uszystkie działania służyły kreacji jego osobistego wizerunku i jednocześnie marki autorskiej, której ideą jest oferowanie czytelnikom literatury gatunkowej wpisującej się $\mathrm{w}$ funkcjonujące trendy, której fabuły byłyby osadzone w polskich realiach, a jednocześnie korespondowałyby ze sposobami ujęcia motywów czy tematów we współczesnej popkulturze.

\footnotetext{
${ }^{20}$ Xięgarnia, odcinek 192, 4.02.2017,prod. TVN24, https://xiegarnia.pl/wideo/xiegarnia-odcinek-192-remigiusz-mroz/ (dostęp: 06.03.2019).

${ }^{21}$ M. Nogaś, «Nogaś na stronie»: czy polskie «House of Cards» jest możliwe?, Wyborcza. pl, 19.02.2017, http://wyborcza.pl/10,82983,21390631,nogas-na-stronie-czy-polskie-house-of-cards-jest-mozliwe.html (dostęp: 06.03.2019).

22 A. Karwouska, Remigiusz Mróz: Czytelnik z czytelnikiem zawsze się zrozumie - nawet jeśli jeden wielbi Joyce'a, a drugi Grishama, Wyborcza.pl Magazyn Świąteczny, 10.02.2018, http://uyborcza.pl/magazyn/7,124059,23004247,remigiusz-mroz-czytelnik-z-czytelnikiem-zausze-sie-zrozumie.html (dostęp: 06.03.2019).

${ }^{23}$ Fotografia R. Mroza na stronie: http://niestatystyczny.pl/2018/08/21/remigiusz-mroz-z-kolejna-ksiazka-o-joannie-chylce/ (dostęp: 06.03.2019).
} 


\section{Zakończenie}

Czy Remigiusz Mróz jest fenomenem u polskim polu kultury drugiej dekady XXI wieku? Niewątpliwie tak, na co uskazuje komercyjny sukces jego twórczości. Jednakże tym, co w kontekście badań polskiego pola literackiego czyni jego postać tak interesującą, jest konsekwencja w zakresie kreacji własnej marki i zarządzania nią za pomocą mediów społecznościouych, co jednoznacznie uskazuje na zaistniałą zmianę kulturą, jaką jest zmniejszająca się rola mediów tradycyjnych w zakresie komunikacji literackiej. Drugą też kuestią, która wynika z obserwacji polskiego pola literackiego, jest jego profesjonalizacja związana z odrzuceniem kultu natchnienia na rzecz codziennego tworzenia, budowania rozpoznawalności i prowadzenia komunikacji z czytelnikami przez wykorzystywanie mediów społecznościouych, co zachodzi zarówno w odniesieniu do subpola literatury wysokoartystycznej, na co uskazują prace Dominika Antonika, jak i w subpolu literatury gatunkowej.

\section{Bibliografia}

Antonik D., Autor jako marka, TAiWPN Universitas, Kraków 2014.

Bourdieu P., Teoria obiektów kulturowych, przeł. A. Zawadzki [w:] Odkrywanie modernizmu. Przektady i komentarze, red. R. Nycz, TAiWPN Universitas, Kraków 1998.

Guzik P., Jest prawnikiem, ma 28 lat i napisał już... 30 książek. Nałóg?, Wyborcza.pl Opole, 3.05.2015, http://opole.wyborcza.pl/opole/1,35086,17852250,Jest_prawnikiem__ma_28_ lat_i_napisal_juz__30_ksiazek_.html (dostęp: 06.03.2019).

Jagielski W., Wojtek Jagielski na żywo - Remigiusz Mróz, 6.11.2017, www.superstacja.tv, http:// wuw.superstacja.tv/program/wojtek-jagielski-na-zywo-remigiusz-mroz,6555416/ (dostęp: 06.03.2019).

Kaczor K., Wit Szostak - wizerunek akademika przeistaczajacego się w literata, „Horyzonty Wychowania" 2017, vol. 16, no. 39, s. 59-74.

Kaczor K., Z „getta” do mainstreamu. Polskie pole literackie fantasy (1982-2012), TAiWPN Universitas, Krakóu 2017.

Karwouska A., Remigiusz Mróz: Czytelnik z czytelnikiem zawsze się zrozumie - nawet jeśli jeden wielbi Joyce'a, a drugi Grishama, Wyborcza.pl Magazyn Świąteczny, 10.02.2018, http:// wyborcza.pl/magazyn/7,124059,23004247,remigiusz-mroz-czytelnik-z-czytelnikiem-zausze-sie-zrozumie.html (dostęp: 06.03.2019).

Literatura polska po 1989 roku w świetle teorii Pierre'a Bourdieu. Podręcznik, red. G. Jankowicz, P. Marecki, M. Sowiński, Korporacja Ha!art, Kraków 2015.

Łobodziński F., Passent A., Xięgarnia, odcinek 192, 4.02.2017,prod. TVN24, https://xiegarnia. pl/wideo/xiegarnia-odcinek-192-remigiusz-mroz/ (dostęp: 06.03.2019).

Mojebestsellery, Nowa część Chytki już w marcu!, granice.pl Wszystko o literaturze, https:// wuw.granice.pl/news/nowa-czesc-chylki-juz-w-marcu/8007 (dostęp: 06.03.2019).

Mróz R., Behawiorysta, Wydawnictwo Filia, Poznań 2016.

Mróz R., Chór zapomnianych głosów, Wydawnictuo Genius Creations, Bydgoszcz 2014.

Mróz R., Czarna Madonna, Wydawnictuo Czwarta Strona, Poznań 2017.

Mróz R., Hashtag, Wydawnictuo Czuarta Strona, Poznań 2018. 
Mróz R., Jak wydać książkę, Remigiusz Mróz blog, http://blog.remigiuszmroz.pl/jak-wydac-ksiazke/ (dostęp: 06.03.2019).

Mróz R., Nieodgadniona, Wydaunictuo Filia, Poznań 2019.

Mróz R., Nieodnaleziona, Wydawnictwo Filia, Poznań 2018.

Mróz R., O pisaniu na chłodno, Wydawnictwo Czuarta Strona, Poznań 2018.

Mróz R., Świt, który nie nadejdzie, Wydawnictwo Czwarta Strona, Poznań 2016.

Mróz R., Turkusowe szale, Wydawnictwo Bellona, Warszawa 2014.

Mróz R., W cieniu prawa, Wydawnictuo Czwarta Strona, Poznań 2016.

Mróz R., Wieża milczenia, Wydawnictwo Damidos, Katowice 2013.

JoAnNa ChYєKa

Mróz R., Kasacja, Wydawnictuo Czuarta Strona, Poznań 2015.

Mróz R., Zaginięcie, Wydawnictuo Czuarta Strona, Poznań 2015.

Mróz R., Rewizja, Wydawnictuo Czwarta Strona, Poznań 2016.

Mróz R., Immunitet, Wydawnictuo Czuarta Strona, Poznań 2016.

Mróz R., Inwigilacja, Wydawnictuo Czuarta Strona, Poznań 2017.

Mróz R., Oskarżenie, Wydawnictuo Czuarta Strona, Poznań 2017.

Mróz R., Testament, Wydaunictuo Czuarta Strona, Poznań 2018.

Mróz R., Kontratyp, Wydawnictwo Czwarta Strona, Poznań 2018.

Mróz R., Umorzenie, Wydawnictuo Czuarta Strona, Poznań 2019.

\section{KOMISARz FoRST}

Mróz R., Ekspozycja, Wydawnictwo Filia, Poznań 2015.

Mróz R., Przewieszenie, Wydawnictwo Filia, Poznań 2016.

Mróz R., Trawers, Wydaunictuo Filia, Poznań 2016.

Mróz R., Deniwelacja, Wydawnictwo Filia, Poznań 2017.

Mróz R., Zerwa, Wydawnictuo Filia, Poznań 2018.

\section{Parabellum}

Mróz R., Prędkość ucieczki, Instytut Wydawniczy Erica, Warszawa 2013.

Mróz R., Horyzont zdarzeń, Instytut Wydawniczy Erica, Warszawa 2014.

Mróz R., Gtębia osobliwości, Wydawnictwo Czuarta Strona, Poznań 2016.

\section{Trylogia z Wysp OWCZych}

Mróz R. jako Løgmansbø Ove, Enklawa, Wydawnictuo Dolnośląskie, Wrocław 2016.

Mróz R. jako Løgmansbø Ove, Połów, Wydawnictuo Dolnośląskie, Wrocław 2016.

Mróz R. jako Løgmansbø Ove, Prom, Wydawnictuo Dolnośląskie, Wrocław 2017.

W KRĘGach WŁadzY

Mróz R., Wotum nieufności, Wydawnictuo Filia, Poznań 2017.

Mróz R., Większość bezwzględna, Wydaunictwo Filia, Poznań 2017.

Mróz R., Władza absolutna, Wydawnictwo Filia, Poznań 2018.

Nogaś M., »Nogaś na stronie«: czy polskie »House Of Cards« jest możliwe?, Wyborcza.pl, 19.02.2017, http://wyborcza.pl/10,82983,21390631,nogas-na-stronie-czy-polskie-house-of-cards-jest-mozliwe.html (dostęp: 06.03.2019).

Pytanie na śniadanie, wydanie z dnia 22.07.2016, http://pytanienasniadanie.tvp.pl/26250763/ remigiusz-mroz-nowa-twarz-polskiego-kryminalu (dostęp: 06.03.2019).

Soboleuska J., Polski horror religijny, „Polityka” 18 lipca 2017, https://www.polityka.pl/tygodnikpolityka/kultura/1712456,1,remigiusz-mroz-o-swojej-literackiej-drodze.read?print=true (dostęp: 06.03.2019). 


\section{Katarzyna Kaczor}

Varga K., Remigiusz Mróz: żadnych ciuchów, samochodów, podróży!, Wyborcza.pl Duży Format, 19.02.2018, http://wyborcza.pl/duzyformat/7,127290,23028230,remigiusz-mroz-zadnych-ciuchow-samochodow-podrozy.html (dostęp: 06.03.2019).

Varga K., Varga uczy się od Remigiusza Mroza, jak pisać i jak zarobić duże pieniądze, Wyborcza.pl Duży Format, 3.12.2018, http://uyborcza.pl/duzyformat/7,127290,24224764,varga-uczy-sie-od-remigiusza-mroza-jak-pisac-i-jak-zarobic.html (dostęp: 06.03.2019).

Wołkanouska-Kołodziej E., Remigiusz Mróz: autor, który rozbił bank, Wyborcza.pl Książki. Magazyn do czytania, 16 maja 2017, Wyborcza.pl, http://wyborcza.pl/ksiazki/7,154165,21786469,remigiusz-mroz-autor-ktory-rozbil-bank.html (dostęp: 06.03.2019). 